\title{
REPORT FROM THE INSTITUTE
}

Personnel: Professor J. M. Bocheński is at present lecturing at the University of Pittsburgh and will be absent from the Institute until the end of December. Dr. T. R. Payne will be lecturing on Marxist-Leninist philosophy at the University of Notre Dame during the Spring semester of 1969. Mr. J. O'Rourke has joined the teaching staff of the Institute.

Students: During the Summer semester, 1968, 60 students took courses at the Institute. Of these 6 received the Diploma in Basic Sovietology. 68 students have enrolled for courses for the Winter semester 1968-69.

Publications: Two new volumes have been added to the Sovietica series. The first, a study by K. von Ballestrem on Soviet metaphysics and theory of knowledge is entitled Die sowjetische Erkenntnismetaphysik und ihr Verhältnis zu Hegel; the second by T. R. Payne is a study of the life and work of S. L. Rubinštejn, entitled S. L. Rubinštejn and the Philosophical Foundations of Soviet Psychology.

Teaching Programme: The following courses are being offered during the Winter semester 1968-69:

Dousse: Russian Language.

Erni: Theologia Orientalium.

Kemball: History of Russia.

Kemball: History of 19th-century Russian Thought.

O'Rourke: Proseminar in General Sovietology.

Payne: Idéologie Communiste.

Payne: General Introduction to Communism.

Révész: Geschichte und Organisation der Kommunistischen Partei.

Révész: Die Erziehung des neuen Menschen in Osteuropa.

The intensive course in the Russian language has now become a regular feature of the teaching programme. Initiated on an experimental basis two years ago, this course is intended to give students joining the Institute a basic knowledge of Russian in a short space of time. 